\title{
Algoritma Naïve Bayes Berbasis Backward Elimination untuk Prediksi Kesiapan Kerja Pada Siswa SMK
}

\author{
Husni Hidayat \\ Email: rajin_pangkal_pandai@hotmail.com \\ ITS NU Pekalongan
}

\begin{abstract}
Abstrak
SMK (Sekolah menengah kejuruan) adalah kegiatan bimbingan belajar vokasi formal dalam mengembangkan bidang keilmuan, kemampuan kepribadian, sikap sosial, pembelajaran, pengembangan karir, perencanaan dan juga bakat siswa dalam memasuki dunia pekerjaan. Berdasarkan data yang ada pada SMK mutu lulusan SMK tidak semua siswanya memenuhi kualifikasi siap bekerja dikarenakan banyak faktor sehingga diperlukan sebuah pengolahan data yang menerapkan metode prediksi dengan teknik data mining. Salah satu teknik data mining adalah teknik klasifikasi yaitu Nä̈ve Bayes, yang mampu menghasilkan nilai akurasi sampai $95.55 \%$ dalam memprediksi kesiapan kerja siswa SMK, Namun dari banyaknya faktor yang berpengaruh pada kesiapan kerja siswa SMK maka dibutuhkan penambahan fitur seleksi Backward Elimination yang mampu meningkatkan akurasi menjadi $96.95 \%$ dengan mengeliminasi beberapa fitur yang tidak relevan terhadap klasifikasi dan mendapat hasil yang lebih baik daripada menggunakan metode Nä̈ve Bayes saja
\end{abstract}

Kata kunci : SMK; nä̈ve bayes; backward elimination; prediksi

\section{Pendahuluan}

Pendidikan merupakan kegiatan mengoptimalkan perkembangan potensi, kecakapan,dan karakteristik pribadi peserta didik [1]. Salah satu bentuk pedidikan kejuruan adalah Sekolah Menengah Kejuruan. Jenjang pendidikan menengah ini memiliki tujuan utama mempersiapkan peserta didik terutama untuk bekerja dalam bidang tertentu [2]. Tumbuhnya minat bekerja tidak lepas dari pengaruh banyak faktor yang ada seperti lingkungan, keluarga, kondisi ekonomi [3]. Dunia usaha/industri sebagai pemakai lulusan dari dunia pendidikan juga memiliki peranan terhadap standar lulusan SMK, sehingga setelah lulus akan lebih mudah beradaptasi dengan dunia usaha/industri [1]. Kemitraan antara dunia usaha dan sekolah merupakan jalinan kerjasama yang dilakukan untuk memperoleh masukan atau keuntungan bagi kedua belah pihak yakni meningkatkan mutu bagi dunia kerja dan meningkatkan lulusan yang terserap dalam dunia kerja.

Dengan semakin majunya teknologi informasi pertumbuhan basis data yang berukuran besar dapat disimpan dan dikumpulkan tentu saja membutuhkan suatu teknik mengolah data yang menggunung menjadi suatu informasi agar dapat memberikan manfaat guna mendukung pengambilan keputusan atau kebijaksanaan. Sekolah sebagai institusi pendidikan menyimpan data-data dalam jumlah yang besar, data-data tersebut dapat dianalisa menggunakan data mining untuk mengekstraksi dan menghasilkan pengetahuan yang memungkinkan bagi sekolah untuk memprediksi kesiapan kerja pada siswa SMK [4].

Dari penjelasan di atas, jelas bahwa melakukan prediksi kebutuhan dunia kerja dari SMK diperlukan sebuah metode prediksi dan juga merupakan hal yang penting bagi sekolah dimasa yang akan datang untuk menentukan kebijaksaan strategis, dan sekolah bisa menggunakan mekanisme pendukung seperti pengawasan, nasihat, orientasi serta kebijakan strategis lainnya [5]. Maka pada penelitian ini untuk mengoptimalkan prediksi kesiapan kerja pada siswa SMK peneliti menggunakan Nä̈ve Bayes dengan perhitungan probabilitas metode klasifikasi guna mengoptimalkan hasil prediksi dari 855 record data yang memiliki 21 atribut serta mengeliminasi atribut yang tidak signifikan maka dilakukan penggabungan Nä̈ve Bayes berbasis 
Backward Elimination. Metode Backward Elimination merupakan metode langkah mundur dalam membentuk sebuah model yang baik dengan meminimalkan/ menghilangkan atribut yang secara signifikan tidak mempengaruhi model, kelebihan spesifik model penggabungan algoritma Naive Bayes dan Backward Elimination pada data set yang akan diteliti dibanding teknikteknik diagnosis lain, Backward Elimination dapat mereduksi atribut data set sehingga dapat meningkatkan akurasi pada Naïve Bayes [10]. ${ }^{\text {. }}$

\section{Metode Penelitian}

Penelitian ini menggunakan data sekunder dari jumlah 855 record, 543 record menghasilkan label Siap memasuki dunia kerja dan 312 record menghasilkan label Belum siap memasuki dunia kerja. Pada penelitian ini peneliti mencoba mengusulkan metode dengan tahap modeling untuk menyelesaikan prediksi kesiapan kerja pada siswa SMK menggunakan dua metode Naïve Bayes dan Backward Elimination.

Setelah melakukan pengujian model menggunakan algoritma Naive Bayes, dimana dataset yang menggunakan Backward Elimination dan yang tidak menggunakan Backward Elimination akan dibandingkan akurasi dan efisiensinya menggunakan Confussion matrix. Peneliti melakukan proses ekperimental menggunakan aplikasi RapidMiner 5.3.013

Evaluasi dan validasi dilakukan dalam tahap ini menggunakan teknik yang ada dalam framework rapidminer versi 5.3.013, yaitu menggunakan teknik Confussion Matrix sebagai evaluasi untuk mengukur akurasi pada model yang digunakan, pengukuran dilakukan dengan menggunakan tabel klasifikasi yang bersifat prediktif sehingga didapatkan nilai accuracy, precision dan recall, untuk menganalisa kinerja dari algoritma dalam melakukan klasifikasi, serta 10-fold Cross Validation untuk validasi model.

\section{Hasil dan Pembahasan}

Dalam eksperimen dan pengujian metode dilakukan uji coba terhadap metode Naïve Bayes dan metode Nä̈ve Bayes berbasis
Backward Elimination, untuk mengetahui seberapa meningkat akurasi dari metode yang digunakan dengan melakukan evaluasi confusion matrix. Tahap selanjutnya adalah melakukan perbandingan model terbaik menggunakan algoritma Nä̈ve Bayes dan algoritma Naïve Bayes berbasis Backward Elimination.

\subsection{Pengujian Nä̈ve Bayes}

Nilai probabilitas terdiri dari 2 Kelas/ label, yaitu: "Siap Bekerja" dan "Belum Siap Bekerja", mempunyai 4 parameter: Sangat Baik, Baik, Kurang, Cukup, dari jumlah Atribut yang ada adalah 21 yaitu: Motivasi Belajar, Hasil Pengalaman Praktik, Hasil Bimbingan Vokasi, Kondisi Ekonomi, Hasil Prestasi Belajar, Informasi Pekerjaan, Ekspektasi Masuk Kerja, Pengetahuan Umum, Tingkat Intelejensi, Bakat, Minat, Sikap, Nilai Nilai, Kepribadian, Keadaan Fisik, Penampilan Diri, Temperamen, Keterampilan, Kreativitas, Kemandirian dan Kedisiplinan. Bisa dijadikan sebagai acuan dalam melakukan prediksi kesiapan kerja pada siswa SMK di masa mendatang. Berikut adalah sampel perhitungan nilai probabilitas dari atribut Motivasi Belajar :

Tabel I. Nilai Perhitungan Probabilitas

\begin{tabular}{ccccc}
\multicolumn{3}{c}{ Motivasi Belajar } & \multicolumn{2}{c}{ Kelas } \\
\cline { 1 - 3 } Parameter & $\begin{array}{c}\text { Siap } \\
\text { Kerja }\end{array}$ & $\begin{array}{c}\text { Belum } \\
\text { Siap } \\
\text { Kerja }\end{array}$ & $\begin{array}{l}\text { Siap } \\
\text { Kerja }\end{array}$ & $\begin{array}{l}\text { Belum } \\
\text { Siap } \\
\text { Kerja }\end{array}$ \\
\cline { 1 - 3 } $\begin{array}{c}\text { Sangat } \\
\text { Baik }\end{array}$ & 82 & 1 & & \\
\cline { 1 - 3 } Baik & 424 & 89 & & \\
\cline { 1 - 3 } Cukup & 32 & 107 & & \\
\cline { 1 - 3 } Kurang & 5 & 115 & & \\
\hline
\end{tabular}

Didapatkan nilai probabilitas dari atribut "Motivasi Belajar", langkah selanjutnya membagi nilai dari setiap parameter dengan jumlah kelas yang sama. Total parameter "Sangat Baik" dengan Kelas "Siap Kerja" dibagi dengan jumlah kelas "Belum Siap Kerja", berlaku juga untuk semua parameter dengan kelas yang sama dan semua atribut dalam dataset kesiapan kerja siswa SMK, maka mendapatkan hasil Sebagai berikut: 
Tabel II. Nilai

\begin{tabular}{ccc}
\hline Parameter & Siap Kerja & $\begin{array}{c}\text { Belum Siap } \\
\text { Kerja }\end{array}$ \\
\hline $\begin{array}{c}\text { Sangat } \\
\text { Baik }\end{array}$ & $82 / 543=0,151$ & $1 / 312=0,003$ \\
\hline Baik & $\begin{array}{c}424 / 543= \\
0,781\end{array}$ & $89 / 312=0,285$ \\
\hline Cukup & $32 / 543=0,059$ & $107 / 312=0,343$ \\
\hline Kurang & $5 / 543=0,009$ & $115 / 312=0,369$ \\
\hline
\end{tabular}

\subsection{Pengujian Nä̈ve Bayes berbasis} Backward Elimination

Pada tahap pengujian menggunakan Backward Elimination dari 21 atribut tereliminasi 5 atribut yang dianggap tidak relevan dan mempengaruhi tingkat akurasi. Hasil Pengalaman Praktik, Bakat, Sikap, Keterampilan dan Kreativitas. Dilihat dari nilai weight yang bernilai 0 artinya tidak berpengaruh sedangkan yang bernilai 1 berpengaruh terhadap hasil prediksi hal ini menjelaskan bahwa dalam perhitungan predikasi tingkat kesiapan kerja siswa SMK secara optimal dapat diprediksi melalui 16 atribut yang dipilih dan megeliminasi 5 atribut.

\subsection{Pengujian Akurasi Nä̈ve Bayes}

Hasil pengujian accuracy dari eksperimen metode algoritma Naïve Bayes menggunakan validasi 10-Fold Cross validation dengan sampling type menggunakan linear sampling diperoleh accuracy sebesar 95.55\%, precision sebesar $96.02 \%$ dan recall sebesar 92.31\% menggunakan tools rapidminer 5.3.013. seperti terlihat dalam tabel 4.6, tabel 4.7 dan Tabel III berikut:

Tabel III. Nlai Akurasi Nä̈ve Bayes Accuracy: $95.55 \%$

\begin{tabular}{lccc}
\hline & $\begin{array}{c}\text { true siap } \\
\text { bekerja }\end{array}$ & $\begin{array}{c}\text { true } \\
\text { belum } \\
\text { siap } \\
\text { bekerja }\end{array}$ & $\begin{array}{c}\text { class } \\
\text { precision }\end{array}$ \\
$\begin{array}{lccc}\text { pred. siap } \\
\text { bekerja }\end{array}$ & 530 & 25 & $95.50 \%$ \\
\hline $\begin{array}{l}\text { pred. } \\
\text { belum siap } \\
\text { bekerja }\end{array}$ & 13 & 287 & $95.67 \%$ \\
$\begin{array}{l}\text { class } \\
\text { recall }\end{array}$ & $97.61 \%$ & $91.99 \%$ & \\
\cline { 1 - 2 } & & &
\end{tabular}

Nilai accuracy $=\frac{T P+T N}{T P+T N+F P+F N} \times 100 \%$

$=\frac{530+287}{530+287+13+25}=\frac{817}{855} \times 100 \%=\mathbf{9 5 . 5 5 \%}$

3.2. Pengujian Akurasi Naïve Bayes berbasis Backward Elimination.

Hasil percobaan dengan algoritma Nä̈ve Bayes berbasis Backward Elimination, menghasilkan akurasi sebesar $96.95 \%$ mengalami peningkatan sebesar $1.4 \%$ dibandingkan tanpa Backward Elimination. Juga menghasilkan 16 atribut yang terbaik yang bernilai satu dan 1 atribut dibuang yang bernilai nol.

Tabel IV. Nilai Akurasi Nä̈ve Bayes berbasis Backward Elimination

\begin{tabular}{lccc}
\hline Accuracy: 96.95\% & & \\
\hline & $\begin{array}{c}\text { true siap } \\
\text { bekerja }\end{array}$ & $\begin{array}{c}\text { belum } \\
\text { siap } \\
\text { bekerja }\end{array}$ & $\begin{array}{c}\text { class } \\
\text { precisi } \\
\text { on }\end{array}$ \\
\hline $\begin{array}{l}\text { pred. siap } \\
\text { bekerja }\end{array}$ & 532 & 15 & $97.26 \%$ \\
\hline $\begin{array}{l}\text { pred. } \\
\text { belum } \\
\text { siap } \\
\text { bekerja }\end{array}$ & 11 & 297 & $96.43 \%$ \\
\hline $\begin{array}{l}\text { Class } \\
\text { recall }\end{array}$ & $97.97 \%$ & $95.19 \%$ & \\
\hline
\end{tabular}

Nilai accuracy $=\frac{T P+T N}{T P+T N+F P+F N} \times 100 \%$ $=\frac{532+297}{532+297+11+15}=\frac{829}{855} \times 100 \%=\mathbf{9 6 . 9 5 \%}$

\section{Kesimpulan}

Dalam penelitian ini dilakukan pengujian model dengan menggunakan Nä̈ve Bayes dan Nä̈ve Bayes berbasis Backward Elimination dengan menggunakan data kesiapan kerja siswa SMK sejumlah 855 record dengan 21 variabel. Model yang dihasilkan diuji untuk mendapatkan nilai accuracy dari setiap algoritma sehingga didapat pengujian dengan menggunakan data set dan setelah dilakukan pengujian didapat nilai accuracy adalah $95.55 \%$. Sedangkan pengujian dengan Nä̈ve Bayes berbasis Backward Elimination dilakukan eliminasi sebanyak 5 atribut yang tidak memberikan kontribusi, dari 21 variabel antara lain: "Hasil Pengalaman Praktik", "Bakat", "Sikap", "Keterampilan" dan "Kreativitas". Didapatkan hasil nilai accuracy 96.95\%. Maka dapat disimpulkan pengujian data kesiapan kerja siswa SMK menggunakan Nä̈ve 
Bayes dan fitur seleksi Backward Elimination didapat metode tersebut lebih akurat dalam penentuan Prediksi kesiapan kerja siswa SMK dibandingkan dengan metode Nä̈ve Bayes tunggal, ditandai dengan peningkatan nilai akurasi sebesar $1.40 \%$.

\section{Daftar Pustaka}

[1] D. Kurniasari dan G. Isnani (2015) "Analisis pelaksanaan kerjasama SMK dengan dunia usaha," Jurnal Pendidikan Bisnis dan Manajemen, pp. 34-40, 2015.

[2] A. Hidayati (2015), "Relevansi kompetensi lulusan sekolah menengah kejuruan dengan kebutuhan dunia usaha dan industri," Pendidikan Ekonomi \& Bisnis, pp. 1-12, 2015.

[3] A. Fitriani, H. dan K (2012). , "Faktor-faktor yang mempengaruhi minat berwirausaha pada siswa kelas XII SMK Negeri 1 Kandeman Kabupaten Batang tahun 2011/2012," Jurusan Pendidikan Ekonomi, pp. 1-5, 2012.

[4] J. Han dan M. Kamber (2006), Data Mining Concepts and Techniques, San Fransisco: Diane Cerra, 2006

[5] A. R. Rozzaqi (2015), "Naïve Bayes dan Filtering Feature Selection Information Gain untuk Prediksi Ketepatan Kelulusan Mahasiswa," Jurnal Informatika, vol. I, pp. 30-41, 2015.

[6] S. B. Martaleli dan S. Nugraha (2014), "Simulasi dan Prediksi Curah Hujan Mingguan Menggunakan Regresi Polinominal Dengan Metode Backward Elimination," Ilmu Komputer, pp. 1-10, 2014.. 